\title{
PENENTUAN OPERATOR KARTU SELULER TERBAIK MENGGUNAKAN METODE AHP(ANALITYCAL HIERARCHY PROCESS)
}

\author{
Rizaldi \\ Sekolah Tinggi Manajemen Informatika Komputer Royal Kisaran, Asahan \\ rizaldipiliang@gmail.com
}

\begin{abstract}
Abstrak - Peranan Teknologi telekomunikasi menjadi sangat penting, terutama dalam mengubah kehidupan masyarakat. Perkembangan teknologi dibidang komunikasi dan informasi kini dapat dinikmati oleh berbagai lapisan masyarakat, Mulai dari lapisan atas, lapisan menengah ataupun lapisan bawah meskipun hasilnya belum memuaskan. Penelitian dengan judul "Sistem Pendukung Keputusan Penentuan Operator kartu seluler terbaik menggunakan metode ahp" bertujuan memberikan kemudahan bagi konsumen yang ingin membeli kartu seluler dari berbagai operator telekomunikasi sesuai sesuai dengan kebutuhan serta hemat dikantong (ekonomis). Banyaknya operator kartu seluler yang disediakan oleh pihak telekomunikasi mempersulit konsumen dalam menentukan pilihan yang tepat, sesuai dengan kriteria yang diinginkan. Penentuan kartu seluler dengan metode ahp merupakan metode yang tepat untuk mengatasi masalah penentuan kartu seluler terbaik dengan banyak kriteria yang ditawarkan dari masing-masing operator. Kriteria tersebut meliputi harga pembelian kartu seluler, tarif, promo dan masa aktif.
\end{abstract}

Kata kunci - Operator kartu seluler, Sistem pendukung Keputusan, Analitycal Hierarchy Process.

Abstract - The role of telecommunication technology becomes very important, especially in changing people's lives. The development of technology in the field of communication and information can now be enjoyed by various layers of society, ranging from the top layer, middle layer or bottom layer although the results have not been satisfactory. The research titled "Decision Support System Determination of the best mobile card operator using ahp method" aims to provide convenience for consumers who want to buy a cellular card from various telecommunications operators according to the needs and economical dikankan dikan (economical). The number of mobile card operators provided by telecommunication parties make it difficult for consumers to make the right choice according to the desired criteria. The determination of a mobile card with the ahp method is an appropriate method to solve the problem of determining the best mobile card with many of the criteria offered from each operator. These criteria include the purchase price of mobile card, tariff, promo and active period.

Keywords - Mobile Card Operator, Decision Support System, Analitycal Hierarchy Process.

\section{PENDAHULUAN}

Perkembangan teknologi dibidang

komunikasi dan informasi kini dapat dinikmati oleh berbagai lapisan masyarakat, Mulai dari lapisan atas, lapisan menengah ataupun lapisan bawah meskipun hasilnya belum memuaskan. Banyaknya operator kartu seluler yang disediakan oleh pihak telekomunikasi mempersulit konsumen dalam menentukan pilihan 
yang tepat, sesuai dengan kriteria yang diinginkan, Alasannya karena masih banyak konsumen yang kurang paham mengenai operator kartu seluler yang tepat dan ekonomis. Untuk itu, konsumen dituntut untuk jeli dalam memilih operator kartu seluler yang sesuai dengan kebutuhan

Dalam hal ini dibuatlah sebuah sistem pengambilan keputusan penentuan operator kartu seluler terbaik menggunakan metode ahp yang didalamnya terdapat beberapa kriteria-kriteria seperti harga, tarif, promo dan masa aktif dengan alternatives seperti Kartu As, Simpati, Loop, Axis dan Im3 Sehingga Jika konsumen ingin membeli kartu seluler sudah tahu mana yang sesuai atau tidak sesuai dengan kenutuhan dan ekonomis (hemat dikantong).

\section{A. $\quad$ Sistem Pendukung Keputusan}

Konsep Sistem Pendukung Keputusan (SPK) / Decision Support System (DSS) pertama kali diungkapkan pada awal tahun 1970-an oleh Michael S. Scott Morton dengan istilah Management Decision System. Sistem tersebut adalah suatu sistem yang berbasis komputer yang ditujukan untuk membantu pengambil keputusan dengan memanfaatkan data dan model tertentu untuk memecahkan berbagai persoalan yang tidak terstruktur.

Istilah SPK mengacu pada suatu sistem yang memanfaatkan dukungan komputer dalam proses pengambilan keputusan. Untuk memberikan pengertian yang lebih mendalam, akan diuraikan beberapa difinisi mengenai SPK yang dikembangkan oleh beberapa ahli, diantaranya

1. Man dan Watson SPK merupakan suatu sistem yang interaktif, yang membantu pengambil keputusan melalui penggunaan data dan modelmodel keputusan untuk memecahkan masalah yang sifatnya semi terstruktur maupun yang tidak terstruktur.

2. Hasan Konsep Sistem Pendukung Keputusan (SPK) ditandai dengan sistem interaktif berbasis komputer yang membantu pengambilan keputusan memanfaatkan data dan model untuk menyelesaikan masalah yang tidak terstruktur. Pada dasarnya SPK dirancang untuk mendukung seluruh tahap pengambilan keputusan mulai dari mengidentifikasikan masalah, memilih data yang relevan, menentukan pendekatan yang digunakan dalam proses pengambilan keputusan, sampai mgevaluasi pemilihan.

3. Peter G.W. Keen dan Scott Morton (1978), dalam McLeod, Jr (2001, p. 351), dalam

Selanjutnya, sistem pendukung keputusan memiliki karakteristik antara lain :

1. Sistem Pendukung Keputusan dirancang untuk membantu pengambil keputusan dalam memecahkan masalah yang sifatnya semi terstruktur ataupun tidak terstruktur dengan menambahkan kebijaksanaan manusia dan informasi komputerisasi.

2. Dalam proses pengolahannya, sistem pendukung keputusan mengkombinasikan penggunaan modelmodel analisis dengan teknik pemasukan data konvensional serta fungsi-fungsi pencari interogasi informasi.

3. Sistem Pendukung Keputusan, dirancang sedemikian rupa sehingga dapat digunakan/dioperasikan dengan mudah.

4. Sistem Pendukung Keputusan dirancang dengan menekankan pada aspek fleksibilitas serta kemampuan adaptasi yang tinggi.

Selanjutnya, sistem pendukung keputusan memiliki Tujuan antara lain:

1. Memberikan dukungan untuk pembuatan keputusan pada masalah yang semi/tidak terstruktur.

2. Memberikan dukungan pembuatan keputusan kepada manajer pada semua tingkat dengan membantu integrasi antar tingkat. 
3. Meningkatkan efektifitas manajer dalam pembuatan keputusan dan bukan peningkatan efisiennya.

\section{B. Analytical Hierarchy Process (AHP)}

Analytical Hierarchy Process (AHP) merupakan bagian dari Sistem Pendukung Keputusan. AHP dikembangkan oleh Dr. Thomas L. Saaty dari Wharton School of Business pada tahun 1970-an untuk mengorganisasikan informasi dan judgement dalam memilih alternatif yang paling disukai (Saaty, 1994). AHP merupakan sebuah metode sistematis untuk membandingkan seperangkat tujuan atau alternatif. Dalam hal ini, AHP merupakan proses perumusan kebijakan yang powerful dan fleksibel dalam menentukan prioritas, membandingkan alternatif dan membuat keputusan yang terbaik ketika pengambil keputusan harus mempertimbangkan aspek kuantitatif dan kualitatif. AHP mengurangi kerumitan suatu keputusan menjadi rangkaian perbandingan satusatu, kemudian mensistesis hasil perbandingan tersebut. Dengan demikian, AHP tidak hanya bermanfaat dalam pembuata Keputusan yang terbaik tetapi juga memberikan dasar yang kuat bahwa keputusan tersebut merupakan keputusan yang terbaik.

Secara grafis, persoalan keputusan AHP dapat dikonstruksikan sebagai diagram bertingkat, yang dimulai dengan sasaran (goal), lalu kriteria level pertama, sub kriteria, dan akhirnya alternatif. AHP memungkinkan pengguna untuk memberikan nilai bobot relatif dari suatu kriteria majemuk (atau alternatif majemuk terhadap suatu kriteria) secara intuitif, yaitu dengan melakukan perbandingan berpasangan (pairwise comparisons). Dr. Thomas L. Saaty, pembuat AHP, kemudian menentukan cara yang konsisten untuk mengubah perbandingan berpasangan, menjadi suatu himpunan bilangan yang merepresentasikan prioritas relatif dari setiap kriteria dan alternatif.

\section{Prinsip Pokok AHP}

Dalam memecahkan persoalan menggunakan AHP memakai tiga prinsip.

Tiga prinsip tersebut adalah:

1. Prinsip Menyusun Hirarki. Manusia mempunyai kemampuan untuk mempersepsi benda dan gagasan, mengidentifikasinya dan mengkomunikasikan apa yang mereka amati. Untuk memperoleh pengetahuan terinci, pikiran kita menyusun realitas yang komplek ke dalam bagian menjadi elemen pokoknya, dan kemudian ke dalam bagiannya lagi, dan seterusnya secara hirarkis.

2. Prinsip Menetapkan Prioritas Manusia juga mempunyai kemampuan untuk mempersepsi hubungan antara hal-hal yang mereka ammati, membandingkan sepasang benda atau hal yan serupa berdasarkan criteria tertentu dan membedakan kedua anggota pasangan itu dengan menimbang intensitas preferensi mereka terhadap hal yang satu dibandingkan dengan lainnya. Kemudian mereka mensistesis penilaian mereka melalui imajinasi atau dalam hal menggunakan analisa hirarki proses, melalui proses logis yang baru dan memperoleh pengertian yang lebih baik tentang keseluruhan sistem.

3. Prinsip Konsistensi Logis Manusia mempunyai kemampuan untuk menetapkan relasi antar obyek-obyek atau pemikiran itu saling terkait dengan baik dan kaitan mereka menunjukkan konsistensi. Konsistensi berarti dua hal, yang pertama bahwa pemikiran atau obyek yang serupa dikelompokkan menurut homogenitas dan relevansinya. Misal, anggur dan kelereng dapat dikelompokkan menurut homogenitas dan relevansinya. Misalnya, anggur dan kelereng dapat dikelompokkan dalam satu set homogeny jika kriteria relevannya adalah kebulatan, tetapi tidak apabila kriterianya adalah rasa. Arti konsistensi yang kedua adalah bahwa intensitas 
relasi antar gagasan atau antar obyek yang didasarkan pada suatu criteria tertentu, saling membenarkan secara logis.

\section{Langkah-langkah metode AHP}

Tahapan dalam melakukan analisis data AHP menurut Saaty (1994) dikemukakan sebagai berikut:

1. Identifikasi sistem, yaitu untuk mengidentifikasi permasalahan dan menentukan solusi yang diinginkan. Identifikasi sistem dilakukan dengan cara mempelajari referensi dan berdiskusi dengan para pakar yang memahami permasalahan, sehingga diperoleh konsep yang relevan dengan permasalahan yang dihadapi.

2. Penyusunan struktur hirarki yang diawali dengan tujuan umum, dilanjutkan dengankriteria dan sub kriteria. Struktur hirarki terbawah berisi kemungkinan alternatif alternatif strategis.

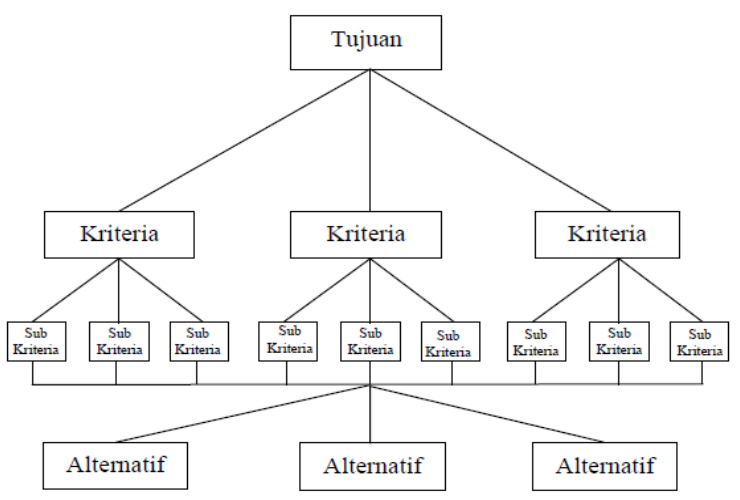

Gambar 1 Struktur Hirarki Metode AHP

Fokus AHP adalah pencapaian tujuan yang akan menghasilkan keputusan yang rasional. Keputusan yang rasional didefinisikan sebagai keputusan terbaik dari berbagai tujuan yang ingin dicapai oleh pembuat keputusan. Kunci utama keputusan yang rasional tersebut adalah tujuan, bukan alternatif, kriteria, atau atribut. Masalah yang dapat diselesaikan dengan menggunakan AHP meliputi masalah sosial, politik dan lain lain.
3. Membuat matriks perbandingan berpasangan, yang menggambarkan pengaruh relatif setiap elemen terhadap masing-masing tujuan atau kriteria yang setingkat diatasnya Perbandingan bersadarkan "judgment" dari pengambil keputusan dengan menilai tingkat kepentingan suatu elemen dibandingkan elemen lainnya. Untuk menilai perbandingan tingkat kepentingan elemen, Saaty (1994) menetapkan skala kuantitatif 1 sampai 9 seperti tabel di bawah ini.

Tabel 1 Skala penilaian perbandingan pasangan

\begin{tabular}{|c|c|}
\hline $\begin{array}{l}\text { Intensitas } \\
\text { Kepentingan }\end{array}$ & Keterangan \\
\hline 1 & Kedua elemen sama pentingnya \\
\hline 3 & $\begin{array}{l}\text { Elemen yang satu sedikit lebih penting daripada } \\
\text { elemen yang lainnya }\end{array}$ \\
\hline 5 & Elemen yang satu lebih penting daripada yang lainnya \\
\hline 7 & $\begin{array}{l}\text { Satu elemen jelas lebih mutlak penting daripada } \\
\text { elemen lainnya }\end{array}$ \\
\hline 9 & Satu elemen mutlak penting daripada elemen lainnya \\
\hline $2,4,6,8$ & $\begin{array}{l}\text { Nilai-nilai antara dua nilai pertimbangan- } \\
\text { pertimbangan yang berdekatan }\end{array}$ \\
\hline
\end{tabular}

4. Menyusun prioritas untuk tiap elemen masalah pada setiap hierarki. Prioritas ini dihasilkan dari suatu matriks perbandingan berpasangan antara seluruh elemen pada tingkat hierarki yang sama.

5. Melakukan pengujian konsistensi terhadap perbandingan antar elemen yang didapatkan pada tiap tingkat hierarki.

Penyimpangan konsistensi dinyatakan dengan Consistency Index (CI) dengan persamaan:

$C I=($ Lamda $\max -\mathrm{n}) /(\mathrm{n}-1)$

Dimana:

Lamda $\max =$ value maksimum $\mathrm{n}=$ jumlah elemen dalam matrik

Untuk mengetahui apakah CI dengan besaran tertentu cukup baik atau tidak, perlu diketahui 
max rasio yang dianggap baik, yaitu apabila $\mathrm{CR} \leq$ 0,1 .

$\mathrm{CR}=\mathrm{CI} / \mathrm{IR}$

CR (Consistency Ratio) merupakan RI parameter yang digunakan untuk memeriksa apakah perbandingan berpasangan telah dilakukan dengan konsekuen atau tidak. Nilai RI merupakan nilai random indeks yang dikeluarkan oleh Oarkridge Laboratory Seperti yan ditampilkan pada tabel berikut:

Tabel 2 Skala Nilai Random Indeks Oarkridge Laboratory

\begin{tabular}{|c|c|c|c|c|c|c|c|c|c|c|c|c|c|c|c|}
\hline $\mathrm{n}$ & 1 & 2 & 3 & 4 & 5 & 6 & 7 & 8 & 9 & 10 & 11 & 12 & 13 & 14 & 15 \\
\hline $\mathrm{RI}$ & 0,00 & 0,00 & 0,58 & 0,90 & 1,12 & 1,24 & 1,32 & 1.41 & 1,45 & 1,49 & 1,51 & 1,48 & 1,56 & 1,57 & 1,59 \\
\hline
\end{tabular}

\section{METODOLOGI PENELITIAN}

Jenis data yang digunakan dalam penelitian ini adalah data primer dan data sekunder. Data primer diperolehan melalui wawancara dan hasil penyebaran kuesioner. Pada saat yang bersamaan penulis juga mencari data sekunder yang berasal dari buku-buku, literatur-literatur, dan artikel- arktikel guna memperkaya pengetahuan dan kemampuan. Sedangkan pengumpulan data dalam penelitian ini, menggunakan beberapa cara, yaitu:

1. Wawancara, dilakukan dalam bentuk tanya jawab kepada responden yang pernah membeli serta menggunakan kartu seluler, sehingga diperoleh informasi mengenai kriteria yang akan digunakan.

2. Kuesioner, dilakukan dengan cara menyebarkan daftar pertanyaan kepada responden yang dianggap pernah membeli serta menggunakan kartu seluler.

3. Studi kepustakaan, pengumpulan data yang dilakukan dengan cara membaca, mengutip secara langsung atau tidak langsung dari buku-buku, literatur-literatur yang bersifat ilmiah, dan media elektronik seperti internet.

\section{HASIL DAN PEMBAHASAN}

Proses awal dilakukan dengan mennetukan kriteria operator kartu seluler yang digunakan dalam menentukan operator kartu seluler terbaik, ada beberapa kriteria yang dipertimbangkan antara lain:

1. Harga: merupakan harga pembelian kartu seluler

2. Tarif: merupakan tarif kertu seluler berupa sms, dan telpon.

3. Promo: merupakan bonus dari kartu seluler

4. Masa Aktif: merupakan lama masa kartu seluler aktif atau dapat digunakan.

Selanjutnya menentukan alternative operator kartu seluler. Untuk menentukan operator kartu seluler terbaik, ada beberapa alternatives yang dipertimbangkan adalah:

1. Kartu As

2. Simpati

3. Axis

4. Loop

5. $\operatorname{Im} 3$

Selanjutnya adalah menentukan matrik perbandingan keputusan operator kartu seluler terbaik Berikut ini adalah tabel matrik perbandingan keputusan operator kartu seluler yang terbaik sebagai berikut:

Tabel 3 Perbandingan berpasangan kriteria operator kartu seluler

\begin{tabular}{|c|c|c|c|c|c|c|c|c|c|c|}
\hline & Harga & Tarif & Promo & Masa aktif & \multicolumn{4}{|c|}{ Bagi Elemen tiap Kolom } & Jumlah & Rata-rata \\
\hline Harga & & 0,5000 & 3 & 0,5 & 0,1875 & 0,1892 & 0,1875 & 0,1852 & 0,7494 & 0,1873 \\
\hline Tarif & 2 & 1 & 7 & 1,0 & 0,3750 & 0,3784 & 0,4375 & 0,3704 & 1,5612 & 0,3903 \\
\hline Promo & 0,3333 & 0,1 & 1 & 0,2 & 0,0625 & 0,0541 & 0,0625 & 0,0741 & 0,2531 & 0,0633 \\
\hline Masa Aktif & 2 & 1 & 5 & 1 & 0,3750 & 0,3784 & 0,3125 & 0,3704 & 1,4362 & 0,3591 \\
\hline Jumlah & 5,3333 & 2,6429 & 16 & 2,7 & & & & & 4 & \\
\hline
\end{tabular}

Dari tabel diatas didapatkan bahwa kriteria yang pertama kali dipertimbangkan konsumen dalam penentuan operator kartu seluler terbaik adalah tarif, masa aktif, harga dan promo. Hasil perhitungan di atas 
didapatkan nilai CR 0,0047, dengan demikian dinyatakan konsistensi karena nilai Consistency Ratio ( CR ) lebih kecil dari $10 \%$. Selanjutnya adalah menentukan matriks perbandingan berpasangan kriteria harga dengan semua alternatives.

Tabel 4 Perbandingan alternative dengan kriteria harga

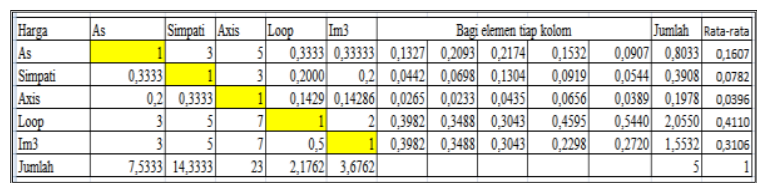

Selanjutnya menentukan matriks perbandingan berpasangan kriteria tarif dengan semua alternatives.

Tabel 5 Perbandingan alternative dengan kriteria tarif

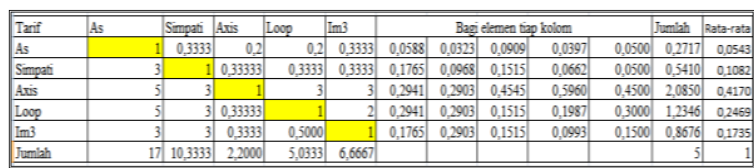

Selanjutnya menetukan matriks perbandingan berpasangan kriteria promo dengan semua alternatives

Tabel 6 Perbandingan alternative dengan kriteria promo

\begin{tabular}{|c|c|c|c|c|c|c|c|c|c|c|c|c|c|}
\hline Promo & As & Simpati & Axis & Lo & & $\operatorname{Im} 3$ & & & Elemen tiap & & & Jumlanh & Rater \\
\hline As & & & & 2 & 0,3333 & 0,33333 & 0,1277 & 0,1875 & 0,2105 & 0,1408 & 0,0862 & 0,7527 & 0,15 \\
\hline impati & 0,3 & & & 0,5 & 0,2000 & 0,2 & 0,0426 & 0,0625 & 0,0526 & 0,0845 & 0,0517 & 0,2939 & 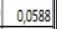 \\
\hline wis & 0,5 & & & 1 & 0,3 & \begin{tabular}{|l|}
0,333333 \\
\end{tabular} & 0,0638 & 0,1250 & 0,1053 & 0,1408 & 0,0862 & 0,5211 & 0,104 \\
\hline Lopp & 3. & & & 3. & 1 & 2 & 0,3830 & 0,3125 & 0,3158 & 0,4225 & 0,5172 & 1,9510 & 0,39 \\
\hline $\mathrm{m}^{3}$ & 3) & 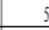 & & 3 & 0,5 & & 0,3830 & 0,3125 & 0,3158 & 0,2113 & 0,2586 & 1,4812 & \\
\hline dath & 333 & 16 & & 9,5 & 2,367 & $\mid 3,86667$ & & & & & & 5 & \\
\hline
\end{tabular}

Selanjutnya menentukan matriks perbandingan berpasangan kriteria masa aktif dengan semua alternatives
Tabel 7 Perbandingan alternative dengan kriteria promo

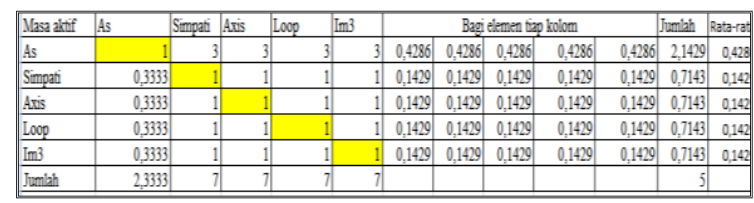

Selanjutnya adalah menentukan rangking dalam mengetahui operator kartu seluler terbaik dibuatlah berupa perangkingan semua alternatives dari keseluruhan kriteria dan didapat hasil sebagai berikut:

Tabel 8 Perangkingan

\begin{tabular}{|l|c|c|}
\hline \multicolumn{1}{|c|}{ Alternative } & Preferensi & Rangking \\
\hline As & 0,215 & 3 \\
\hline Simpati & 0,112 & 5 \\
\hline Axis & 0,228 & 2 \\
\hline Loop & 0,249 & 1 \\
\hline Im3 & 0,196 & 4 \\
\hline
\end{tabular}

Selanjutnya adalah melakukan pengujian dengan menggukan sofware super decission untuk membandingkan hasil yang didapat melalui proses AHP. Berikut adalah hasil pengolahan melalui software super decission.

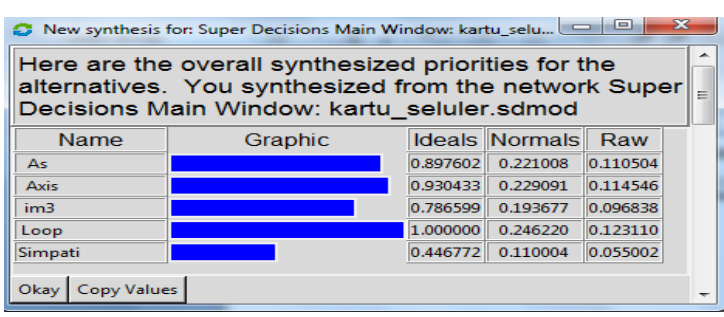

Gambar 2 Hasil perangkingan melalui proses software Super Decission 
IV. KESIMPULAN

Dari hasil penelitian yang dilakukan pada konsumen yang pernah membeli dan memakai kartu As, Simpati, Axis, Loop dan Im3 mulai dari harga pembelian awal, tarif, promo dan masa aktif dapat disimpulkan bahwa Kartu Loop merupakan kartu seluler yang terbaik dan dalam hal pembelian untuk pemakaian kartu seluler yang paling utama dipertimbangkan konsumen adalah tarif.

\section{SARAN}

Saran-saran yang dapat penulis sampaikan terkait dengan hasil penelitian ini adalah :

1. Penelitian ini dapat dikembangkan lebih lanjut dengan penajaman dan penambahan pada atribut kriteria, sub kriteria dan juga alternatif.

2. Pihak yang memberikan penilaian perlu memiliki pengetahuan yang cukup terhadap topik yang dianalisis, untuk menghindari rasio inkonsistensi yang tinggi.

3. Perlunya tingkat konsentrasi yang tinggi pada saat memberikan penilaian pada topik yang analisis dapat menyebabkan hasil penilaian yang konsisten.

4. Dasar keputusan dari AHP adalah mengandalkan persepsi para ahli, oleh sebab itu AHP seyogyanya hanya digunakan ketika masalah yang dihadapai memang sesuai dengan kerangka teori dari AHP. Di samping itu, perlu juga kehati-hatian dalam menginterptetasikan hasil-hasil yang diperoleh dengan AHP.

5. Penelitian ini sebaiknya dilakukan secara periodik untuk mengetahui setiap perubahan yang bisa menentukan kebijakan dalam pengambilan keputusan.

\section{DAFTAR PUSTAKA}

[1] Alonso, J. A., dan Lamata, M. T., 2006, Concistency In The Analytical Hierarchy Process:

A New Approach, International Journal of Uncertainty, no 4, volume 14, hal.445-459.

[2] Azmi, M., Sonatha, Y., Rasyidah, 2014, Pemanfaatan Sistem Pendukung Keputusan Untuk Penentuan Alokasi Dana Kegiatan (Studi Kasus Unit Kegiatan Mahasiswa Politeknik Negeri Padang), Jurnal Momentum, Vol 16, No 1, Hal 74-83.

[3] Dyah, N.R, dan Maulana, A, 2009. "Sistem Pendukung Keputusan Perencanaan Strategis Kinerja Instansi Pemerintah Menggunakan Metode AHP (Studi kasus Deperindag)", Jurnal Informatika - Vol 3 No.2.

[4] Efrain, Turban. 2005. Decision Support Systems and Intelligent System. New Jersey: Prentice Hall Inc.

[5] L. Saaty, Thomas, 1993, Pengambilan keputusan bagi para pemimpin, PTPustaka Binaman Pressindo.

[6] Turban, Efraim, Jay E. Aronson, Ting-Peng Liang. 2005. Decision support system and intelligent system (Sistem pendukung keputusan dan sistem cerdas). (Dwi Prabantini, Penerjemah). Yogyakarta. ANDI. 